\title{
Glacier mass variation and its effect on surface runoff in the Beida River catchment during 1957-2013
}

\author{
SHENG WANG, ${ }^{1,3}$ TANDONG YAO, ${ }^{1}$ LIDE TIAN, ${ }^{1}$ JIANCHEN PU ${ }^{2}$ \\ ${ }^{1}$ Key Laboratory of Tibetan Environment Changes and Land Surface Processes, Institute of Tibetan Plateau Research, \\ Chinese Academy of Sciences, Beijing, China \\ ${ }^{2}$ State Key Laboratory of Cryospheric Sciences, Northwest Institute of Eco-environment and Resources, Chinese Academy \\ of Sciences, Lanzhou, China \\ ${ }^{3}$ University of Chinese Academy of Sciences, Beijing, China \\ Correspondence to: Tandong Yao <tdyao@itpcas.ac.cn>
}

\begin{abstract}
Using in-situ measured data from Qiyi Glacier, in combination with meteorological and runoff data from stations, a distributed degree-day model was developed for 631 investigated glaciers in the Beida River catchment to explore glacier mass change and its effect on streamflow. The results showed that the average mass balance was $-272 \pm 67 \mathrm{~mm}$ w.e. $\mathrm{a}^{-1}$, with an ice loss of $3.99 \mathrm{Gt}$ during 19572013. Assuming a continuous linear trend, equilibrium line altitude rose by $242 \mathrm{~m}$. Compared with morpho-topographic variables, climatic control is a more important factor affecting glacier change. Mass-balance sensitivity to air temperature was $-239 \mathrm{~mm}$ w.e. ${ }^{\circ} \mathrm{C}^{-1} \mathrm{a}^{-1}$, while to precipitation it was $+1.1 \mathrm{~mm}$ w.e. $\mathrm{mm}^{-1} \mathrm{a}^{-1}$. That is, a $210 \mathrm{~mm}$ increase in precipitation would be needed to compensate for the net mass loss induced by an air temperature increase of $1^{\circ} \mathrm{C}$. Average annual glacier meltwater runoff was $1.51 \times 10^{8} \mathrm{~m}^{3}$ from 1957 to 2013 , accounting for $15.2 \%$ of surface runoff. The time series of meltwater runoff changed abruptly in 2000, and its contribution to surface runoff increased from 13.9 to $\mathbf{2 0 . 4} \%$.
\end{abstract}

KEYWORDS: climate change, glacier hydrology, glacier mass balance, glacier modelling

\section{INTRODUCTION}

Mountain glaciers are the water towers of the world (Viviroli and others, 2007). Although only covering 3\% of the earth's total glacierized land area (Meier, 1984; Arendt and others, 2002), small glaciers and ice caps (excluding the Antarctic and Greenland ice sheets) play an important role in assessing and predicting sea level change on decadal to centurial timescales (Oerlemans and Fortuin, 1992). Previous studies have indicated that these glaciers, whose shrinkage has tended to accelerate with the ongoing climate warming (Kaser, 1999; Arendt and others, 2002; Paul and others, 2004; Meier and others, 2007; Yao and others, 2012), contributed $~ 20-60 \%$ to rising sea level in different periods (Meier, 1984; Kaser and others, 2006; Meier and others, 2007; Gardner and others, 2013). Small glaciers have a shorter response time to climate change than the large ice sheets of Greenland and Antarctica, and their contribution may be even more if the climate continues to warm (Oerlemans and Fortuin, 1992). Variations in mountain glaciers are acknowledged to be among the best natural indicators of climate change. In contrast to variations in glacier length or area, variations in mass balance and equilibrium line attitude (ELA) are direct responses to glacier mass and climate change (Bolch and others, 2012).

Modeling is one of the major techniques for assessing glacier mass balance and ELA. The energy-balance and degree-day models are two widely applicable methods. Energy-balance models can describe the physical processes of a glacier surface in detail, but their parameters and input data are not readily available due to observational restrictions. On the contrary, degree-day models rely upon the relationship between snow or ice melt and positive temperatures
(Hock, 2003). On account of the wide availability and easy interpolation of air temperature data, the models are widely used in mass-balance estimation for a single glacier (Jóhannesson and others, 1995; Braithwaite and Zhang, 2000; Pellicciotti and others, 2005; Azam and others, 2014; Gao and others, 2015; Liu and Liu, 2016). At present, the distributed degree-day models are subjected to the considerable simplification that is necessary for operation at large scales (e.g., global or regional), and for estimation of the contribution of glaciers to sea level change (Raper and Braithwaite, 2006; Radić and Hock, 2011; Marzeion and others, 2012; Giesen and Oerlemans, 2013; Slangen and others, 2016). The simulated accuracy of degree-day models often outperforms energy-balance models on a catchment scale (Hock, 2003).

The Beida River is located in an arid and semi-arid region in northwest China. In the catchment, glaciers are significant contributors to streamflow, serving as a frozen reservoir that supplements runoff during warm and dry periods. Approximately $15 \%$ of the runoff is from glaciers, and the rate will increase with the ongoing climate warming. The accelerated glacier retreat has significant implications for downstream oasis farming, regional water supplies and the sustainability of aquatic ecosystems (Shi and Zhang, 1995; Wang and others, 2001; Yang and others, 2004; Liu and others, 2006). A study on glacier mass variation and its effect on surface runoff in Beida River catchment has important theoretical and practical significance. In the present study, using in-situ measured data from Qiyi Glacier and meteorological and run-off data from stations, we developed a distributed degree-day model at $1 \mathrm{~d}$ temporal resolution and $90 \mathrm{~m}$ spatial resolution. The aims of this study are to 
reconstruct the time series of mass balance and ELA in the Beida River catchment from 1957 to 2013, analyze the causes of glacier mass balance and ELA changes and discuss the essential relationships between glaciers, climate and runoff.

\section{STUDY AREA, DATA AND METHOD}

\subsection{Selection of study area}

The Beida River catchment $\left(97^{\circ} \sim 99.5^{\circ} \mathrm{E}, 38^{\circ} \sim 40^{\circ} \mathrm{N}\right)$ is located in the upper reaches of the Heihe River (Fig. 1), which is the second biggest inland river in China. There are three tributaries in the catchment, from east to west, the Fengle River, Hongshui River and Tuolai River, with drainage areas of 565, 1578 and $6706 \mathrm{~km}^{2}$, respectively. Glacier meltwater has played a significant role in the development of downstream industry and agriculture. In the present study, we investigated a total of 631 glaciers, which had a total estimated area of $318.2 \mathrm{~km}^{2}$ and an average area of $0.5 \mathrm{~km}^{2}$. The glaciers are small in size; $87.6 \%$ of glaciers are $<1 \mathrm{~km}^{2}$, and only two glaciers are $>5 \mathrm{~km}^{2}$.

Qiyi Glacier $\left(39.5^{\circ} \mathrm{N}, 97.5^{\circ} \mathrm{E}\right)$ is located in the northwest of the Beida River catchment, and its meltwater flows into the Liuquangou River, which is a branch of the Tuolai River. This glacier has an interrupted observational time series spanning more than 20 years (1975-78, 1985-88 and 2000-13), and has good representation in the study area. Regional representation was based on the following criteria: (1) glacier is small in size, and the area is only $2.76 \mathrm{~km}^{2}$ ( $\mathrm{Pu}$ and others, 2005); (2) corresponding to $4003 \mathrm{~m}$ (minimum), $5531 \mathrm{~m}$ (maximum) and $4759 \mathrm{~m}$ (mean) of the glaciers elevation in the Beida River catchment, the elevation of Qiyi Glacier is from $4304 \mathrm{~m}$ in the terminus to $5159 \mathrm{~m}$ in

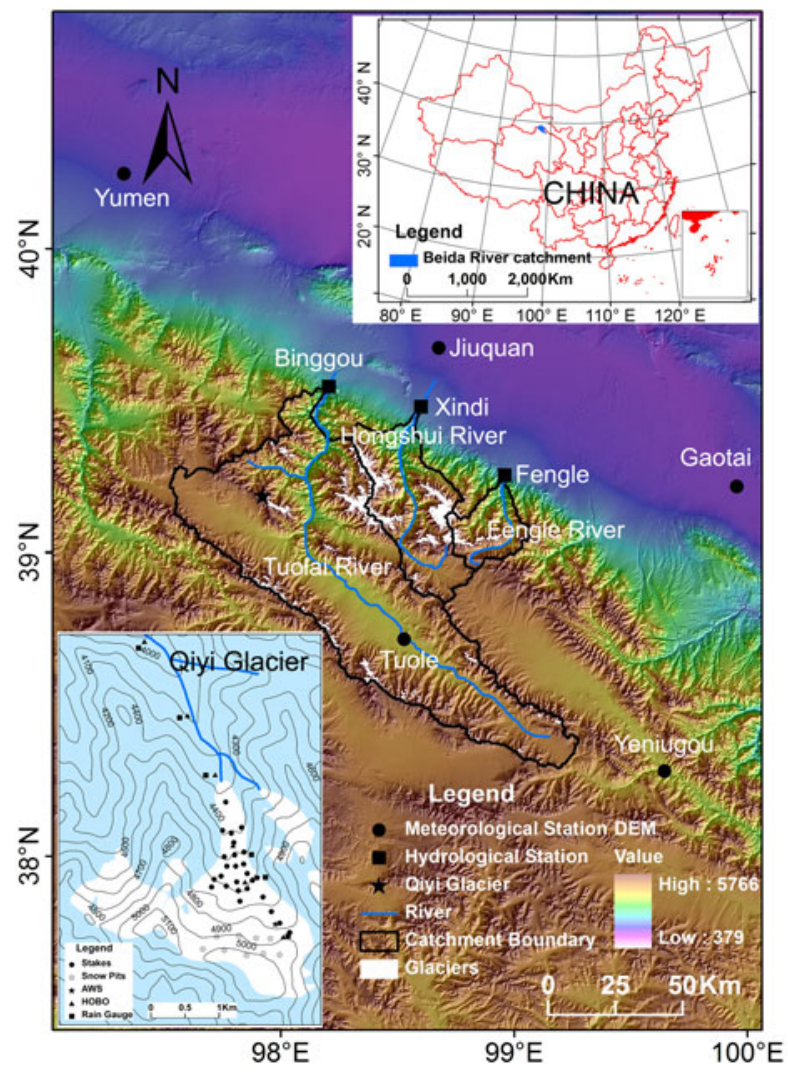

Fig. 1. Location of the Beida River catchment and observation in Qiyi Glacier. the peak, and the average elevation is $4807 \mathrm{~m}$; (3) corresponding to $25.7^{\circ}$ of the average glaciers slope in the catchment, the average slope of Qiyi Glacier is $20^{\circ}$; (4) $32.3 \%$ of the glaciers in the catchment, which is the highest percentage, have the same aspect as the Qiyi Glacier (northwest); (5) according to the physical characteristics of glaciers, the Qiyi Glacier is classed as a sub-continental glacier, which is the same as most glaciers in the catchment.

\subsection{Data}

The datasets used in this study include: meteorological data, satellite data, field-based measurements from Qiyi Glacier and hydrological data.

\subsubsection{Meteorological data}

Five meteorological stations (Table 1, Fig. 1) around the catchment were selected, and meteorological data included the daily air temperature, precipitation, relative humidity, barometric pressure and sunshine duration. Among them, the data from a mountain meteorological station (Tuole) was used for driving the model and the rest were used for analyzing the response of glaciers to climate change. The datasets were derived from the China Meteorological Data Sharing Service System (http://data.cma.cn/).

\subsubsection{Satellite data}

Considering the variations in glacier area from 1957 to 2013, glacier boundaries used in the model were distinguished into two periods: glacier boundaries between 1957 and 1985 were extracted from topographic maps of the 1970s; and glacier boundaries between 1986 and 2013 were taken from a satellite image from 2000. Fifteen topographic maps (1: 100000$)$ from the 1970s that were derived from aerial photographs taken by the Chinese Military Geodetic Service were selected. The satellite imagery was one Landsat TM image (P133 r33, 2000-5-20) that was taken in cloud-free conditions, with a spatial resolution of $30 \mathrm{~m}$ (http://www.usgs.gov/). The pretreatment of topographic maps included scanning, creating mosaics and Image registration; the Image registration and geocorrection of satellite imagery were accomplished in ArcGIS 9.3 software. Glacier boundaries were extracted by visual interpretation. A DEM of the catchment was derived from the Shuttle Radar Topography Mission, with a resolution of $90 \mathrm{~m}$. The DEM was used to compute the following morpho-topographic variables of each glacier: average elevation, slope, aspect, latitude and longitude of the glacier centroid. All maps and images were projected into the Universal Transverse Mercator coordinate system referenced to the 1984 World Geodetic System.

\subsubsection{Field-based measurements in Qiyi Glacier}

The datasets included mass balance data, air temperature and precipitation data from different altitude intervals, and meteorological data from an automatic weather station (AWS). The mass balance measurement and calculation were using the same methods presented by Yao and others (2012). A monthly observation of mass balance was carried out from July 2011 to August 2013. Synchronously, air temperature and precipitation from different altitude intervals were measured by seven pairs of hygrothermographs and rain gauges (Fig. 1). The AWS was located at an altitude of 
Table 1. Meteorological and hydrological stations in this study

\begin{tabular}{|c|c|c|c|c|c|}
\hline & Station & Latitude ${ }^{\circ} \mathrm{N}$ & Longitude ${ }^{\circ} \mathrm{E}$ & Altitude m & Observed Period \\
\hline \multirow[t]{5}{*}{ Meteorological station } & Tuole & $38^{\circ} 48^{\prime}$ & $98^{\circ} 25^{\prime}$ & 3367 & 1957.1.1-2013.12.31 \\
\hline & Yeniugou & $38^{\circ} 25^{\prime}$ & $99^{\circ} 35^{\prime}$ & 3320 & 1960.1.1-2013.12.31 \\
\hline & Yumen & $40^{\circ} 16^{\prime}$ & $97^{\circ} 02^{\prime}$ & 1526 & 1953.1.1-2013.12.31 \\
\hline & Jiuquan & $39^{\circ} 46^{\prime}$ & $98^{\circ} 29^{\prime}$ & 1477.2 & 1951.1.1-2013.12.31 \\
\hline & Gaotai & $39^{\circ} 22^{\prime}$ & $99^{\circ} 50^{\prime}$ & 1332.2 & 1953.1.1-2013.12.31 \\
\hline \multirow[t]{2}{*}{ Hydrologicl station } & Binggou & $39^{\circ} 36^{\prime}$ & $98^{\circ} 00^{\prime}$ & 2015 & 1957.1.1-2013.12.31 \\
\hline & Fengle & $39^{\circ} 34^{\prime}$ & $98^{\circ} 25^{\prime}$ & 2000 & 1957.1.1-2013.12.31 \\
\hline
\end{tabular}

$4763 \mathrm{~m}$ a.s.I.. Observed items of the AWS included wind speed and direction, air temperature, relative humidity, barometric pressure, snow depth and 4-component radiation (incoming and reflected shortwave radiation, incoming and outgoing longwave radiation). All of the above datasets were used for calibrating the parameters in the model, and mass balance and ELA data quoted from the papers published in the referred journals were used for validating the simulated results (Wang and others, 1984, 2011; Liu and others, 1992; Pu and others, 2005; Wang and others, 2011; Yao and others, 2012).

\subsubsection{Hydrological data}

The Binggou, Xindi and Fengle hydrological stations were respectively, located in the Tuolai River, Hongshui River and Fengle River catchments (Table 1, Fig. 1), which controlled the surface runoff of each river. Annual and monthly run-off data of the Binggou, Xindi and Fengle hydrological stations from 1957 to 2013 were selected to discuss the essential relationships between glaciers and runoff. The datasets were derived from the China Hydrological Almanac and Environmental and the Ecological Science Data Center in Western China (http://westdc.westgis.ac.cn/).

\subsection{Method}

\subsubsection{Model description}

The distributed degree-day mass-balance model in the Beida River catchment can be described over any period of time with the following formula (Oerlemans and Fortuin, 1992):

$$
B=\int_{t}\left[(1-f) m+P_{\mathrm{s}}\right] d t
$$

where $B$ (mm w.e.) is the glacier mass balance; $f(f=0.076)$ is the fraction of refreezing meltwater that is calculated by a multilevel snowmelt model (Yang and others, 2013); $m$ ( $\mathrm{mm}$ w.e.) is the ablation water equivalent of ice and snow; $P_{\mathrm{s}}$ (mm w.e.) is the accumulation which is equal to solid precipitation; and $t$ is the selected period.

An improved degree-day model (Pellicciotti and others, 2005) was used to simulate ice and snowmelt:

$$
m=\left\{\begin{array}{cc}
T F \cdot T+S R T \cdot(1-\alpha) \cdot S_{i n}^{i} & T>0 \\
0 & T \leq 0
\end{array}\right.
$$

where $T F\left(\mathrm{~mm}^{\circ} \mathrm{C}^{-1} \mathrm{~d}^{-1}\right)$ and $S R T\left(\mathrm{~m}^{2} \mathrm{~mm} \mathrm{~W}^{-1} \mathrm{~d}^{-1}\right)$ are the degree-day factors. $T F$ and $S R T$, which are obtained by using the multiple linear regression method, are different for different underlying surfaces (for ice, $T F=4.52, S R T=$ 0.0035; and for snow, $T F=1.64, S R T=0.0075) ; T\left({ }^{\circ} \mathrm{C}\right)$ is the daily average air temperature $2 \mathrm{~m}$ above glacier surface; $\alpha$ is the albedo; and $S_{i n}^{i}\left(\mathrm{~W} \mathrm{~m}^{-2}\right)$ is the incoming shortwave radiation at a given grid cell $(i)$ on the glacier surface.

The incoming shortwave radiation $\left(S_{i n}^{i}\right)$ is constituted by the direct radiation $(I)$ and diffuse radiation $(D)$. The partitioning between direct and diffuse radiation depends linearly on cloudiness, and the fraction of diffuse radiation $\left(D_{\mathrm{F}}\right)$ can be calculated (Oerlemans, 1992; Brock and Arnold, 2000; Sicart and others, 2011):

$$
\begin{gathered}
D_{\mathrm{F}}=0.65 n+0.15 \\
n=\frac{S_{i n}^{\text {Tuole }}}{K}
\end{gathered}
$$

where $n$ is the cloudiness. For total cloud cover, $80 \%$ of the global radiation diffuses, whereas for clear-sky conditions it is only $15 \%$. $S_{i n}^{\text {Tuole }}$ is the incoming shortwave radiation at Tuole station, and these data are from the Institute of Tibetan Plateau Research, Chinese Academy of Sciences (ITPCAS) radiation forcing data (http://dam.itpcas.ac.cn/rs/?q=data). $K$ is the potential direct solar radiation at the glacier surface without clouds, which is calculated as (Hock, 1999):

$$
K=I_{0} \cdot\left(\frac{R_{\mathrm{m}}}{R}\right)^{2} \cdot \psi_{\mathrm{a}}^{\left(\frac{P}{P_{0} \cos Z}\right)} \cdot \cos \theta
$$

where $I_{0}\left(1362 \mathrm{~W} \mathrm{~m}^{-2}\right)$ is the solar constant; $\left(R_{\mathrm{m}} / R\right)$ is the correction factor of earth's orbit eccentricity; $R$ is the instantaneous earth-sun distance; $R_{\mathrm{m}}$ is the average earth-sun distance; $\psi_{\mathrm{a}}$ is the average atmospheric clear-sky transmissivity, with a value of 0.6 or 0.7 generally; $P_{0}(1013.25 \mathrm{hPa})$ is the standard atmospheric pressure; $P(\mathrm{hPa})$ is the atmospheric pressure at different altitudes; $Z$ is the local zenith angle; and $\theta$ is the angle of incidence between the normal to the grid slope and the solar beam.

The direct radiation $(I)$ at a given point on a glacier surface without terrain shading could be calculated (Arnold and others, 1996):

$$
\begin{aligned}
I= & \left(1-D_{\mathrm{F}}\right) \cdot \vec{S}_{\text {in }} \cdot[\sin Z \cos \beta \\
& \left.+\cos Z \sin \beta \cos \left(\phi_{\text {sun }}-\phi_{\text {aspect }}\right)\right]
\end{aligned}
$$

where $\beta$ is the slope angle, $\varphi_{\text {sun }}$ and $\varphi_{\text {aspect }}$ are the solar azimuth and the slope azimuth (aspect) angle, respectively. $\vec{S}_{\text {in }}$ is the normal incident direct solar radiation at the same 
point:

$$
\vec{S}_{\text {in }}=S_{\text {in }}^{\text {Tuole }} / \sin Z
$$

The diffuse radiation $(D)$ is constituted by the diffuse radiation in the sky and shortwave radiation reflected by the surrounding terrain:

$$
D=D_{0} \cdot V_{s k y}+\alpha_{m} \cdot \vec{S}_{i n} \cdot\left(1-V_{s k y}\right)
$$

where $D_{0}$ is the diffuse radiation in the sky without the terrain shading; $\alpha_{\mathrm{m}}\left(\alpha_{\mathrm{m}}=0.3\right)$ is the average albedo of the surrounding terrain; and $V_{s k y}$ is the view factor of sky. If $V_{s k y}=1$, the given grid cell was not shaded by the surrounding terrain; on the contrary, if $V_{s k y}=0$, the grid cell was shaded. In this study, the terrain shading effect is determined by the ray tracing method (Arnold and others, 1996).

Albedo is among the key indicators of simulated accuracy. The albedo of the glacier surface is closely related to the number of days after snow. On one hand, the number of days after snow reflects the metamorphism of snow with time; on the other hand, it also reflects the accumulation effect of surface contamination over time. In this study, we used a parameterization scheme proposed by Oerlemans and Knap (1998):

$$
\alpha^{(i)}=\alpha_{\text {snow }}^{(i)}+\left(\alpha_{\text {ice }}-\alpha_{\text {snow }}^{(i)}\right) \exp \left(\frac{-d}{d^{*}}\right)
$$

where $\alpha^{(i)}$ is the albedo at a given grid cell (i) in glacier surface; $d$ $(\mathrm{cm})$ is the snow depth; $d^{*}\left(d^{*}=1.91 \mathrm{~cm}\right)$ is a characteristic scale for snow depth; and $\alpha_{i c e}$ is the albedo of ice, which is calculated by the following formula (Mölg and others, 2008):

$$
\alpha_{i c e}=a T_{c}+b
$$

where $T_{\mathrm{c}}$ is the dew point temperature; $a(a=0.075)$ and $b$ $(b=0.13)$ are constants; the albedo of snow surface $\alpha_{\text {snow }}^{(i)}$ is determined by the number of days after snow:

$$
\alpha_{\text {snow }}^{(i)}=\alpha_{\text {firn }}+\left(\alpha_{\text {fresnow }}-\alpha_{\text {firn }}\right) \exp \left(\frac{s-i}{t^{*}}\right)
$$

where $\alpha_{\text {firn }}\left(\alpha_{\text {firn }}=0.7\right)$ is the albedo for firn, $\alpha_{\text {frsnow }}$ $\left(\alpha_{\text {frsnow }}=0.91\right)$ is the albedo for fresh snow; $s$ is the number of the day on which the last snowfall occurred; and $t^{*}\left(t^{*}=1.73\right)$ is the timescale for snow metamorphism. All the parameters are determined by the least squares method.
The solid precipitation is calculated by the threshold temperature method (Kang and others, 1999):

$$
\begin{gathered}
P_{\mathrm{s}}=\left\{\begin{array}{cc}
P_{\text {total }} & T<T_{\mathrm{s}} \\
\frac{T_{\mathrm{r}}-T}{T_{\mathrm{r}}-T_{\mathrm{s}}} \cdot P_{\text {total }} & T_{\mathrm{s}} \leq T \leq T_{\mathrm{r}} \\
0 & T>T_{\mathrm{r}}
\end{array}\right. \\
P_{\mathrm{r}}=P_{\text {total }}-P_{\mathrm{s}}
\end{gathered}
$$

where $P_{\mathrm{s}}, P_{\mathrm{r}}$ and $P_{\text {total }}(\mathrm{mm})$ are snow, rain and total precipitation, respectively; $T_{\mathrm{s}}$ and $T_{\mathrm{r}}$ are the threshold temperatures for snow/rain transition, with the values of -1.05 and $0.64{ }^{\circ} \mathrm{C}$, respectively (using the Monte Carlo method, which runs modeling for a total of 1000 times to yield the minimum of RMSD between measured and modeled mass balance of Qiyi Glacier).

\subsubsection{Parameters calibration}

According to the in-situ measurements of air temperature and precipitation at different altitudes on Qiyi Glacier from 2011 to 2012 , the lapse rate of air temperature was $0.70^{\circ} \mathrm{C}(100$ $\mathrm{m})^{-1}$. The observed site with maximum precipitation was located at $4670 \mathrm{~m}$ a.s.l., where the annual precipitation was $410.5 \mathrm{~mm}$. The observations were similar to measured results $\left(0.73^{\circ} \mathrm{C} 100 \mathrm{~m}^{-1}\right.$ and $\left.485 \mathrm{~mm}^{-1}\right)$ by Wang and others. (2009) in 2007/08. To improve the simulated precision, we used different temperature and precipitation lapse rates in different months and altitude intervals, and considered the temperature difference between non-glacial and glacial regions when calculating the lapse rates. The details are shown in Tables 2-4.

\subsubsection{Results validation}

Figure 2a shows the simulated and observed annual balance of Qiyi Glacier. Simulations of annual balance were in accord with observations (correlation coefficient, $R=0.91$ ), especially after 2006/07 $(R=0.98)$. The simulated and observed average mass balances were, respectively, -264

\begin{tabular}{|c|c|c|c|c|c|c|c|c|c|c|c|c|}
\hline Month & January & February & March & April & May & June & July & August & September & October & November & December \\
\hline Temperature difference & 0.37 & 037 & 0.48 & 0.79 & 0.82 & 0.14 & 1.21 & 0.53 & 0.07 & 0.68 & 0.47 & 0.51 \\
\hline
\end{tabular}
and $-250 \mathrm{~mm}$ w.e. $\mathrm{a}^{-1}$, with a relative error of $5.7 \%$, and the relative error reduced to $0.7 \%$ after $2006 / 07$. In the

\begin{tabular}{|c|c|c|c|c|c|c|c|c|c|c|c|c|}
\hline $\begin{array}{l}\text { Month } \\
\text { Altitude }\end{array}$ & January & February & March & April & May & June & July & August & September & October & November & December \\
\hline$<3975 \mathrm{~m}$ & 0.42 & 0.53 & 0.6 & 0.66 & 0.75 & 0.68 & 0.69 & 0.61 & 0.74 & 0.54 & 0.58 & 0.39 \\
\hline 3795-4101 m & 0.57 & 0.49 & 0.5 & 0.65 & 0.69 & 0.6 & 0.35 & 0.46 & 0.47 & 0.47 & 0.5 & 0.57 \\
\hline 4101-4304 m & 0.61 & 0.51 & 0.53 & 0.69 & 0.73 & 0.63 & 0.86 & 0.67 & 0.71 & 0.49 & 0.53 & 0.6 \\
\hline 4304-4392 m & 0.4 & 0.52 & 0.59 & 0.65 & 0.74 & 0.67 & 0.51 & 0.53 & 0.66 & 0.53 & 0.57 & 0.37 \\
\hline $4392-4470 \mathrm{~m}$ & 0.52 & 0.69 & 0.51 & 0.86 & 0.83 & 0.56 & 0.95 & 0.87 & 0.64 & 0.53 & 0.43 & 0.34 \\
\hline 4470-4608 m & 0.49 & 0.45 & 0.45 & 0.49 & 0.64 & 0.49 & 0.49 & 0.58 & 0.67 & 0.41 & 0.47 & 0.43 \\
\hline$>4608 \mathrm{~m}$ & 0.67 & 0.63 & 0.45 & 0.69 & 0.62 & 0.45 & 0.58 & 0.64 & 0.38 & 0.47 & 0.48 & 0.5 \\
\hline
\end{tabular}
monthly mass-balance simulation (Fig. 2b), the correlation coefficient between the simulated and observed monthly balance was 0.92. Simulated results of the cold season

Table 2. Temperature difference between non-glacial and glacial regions in different months of Qiyi Glacier $\left({ }^{\circ} \mathrm{C}\right)$

Table 3. Lapse rates of temperature in different months and altitude intervals $\left({ }^{\circ} \mathrm{C}(100 \mathrm{~m})^{-1}\right)$ 
Table 4. Precipitation gradients in different months and altitude intervals $\left(\mathrm{mm}(100 \mathrm{~m})^{-1} \mathrm{~d}^{-1}\right)$

\begin{tabular}{|c|c|c|c|c|c|c|c|c|c|c|c|c|}
\hline $\begin{array}{l}\text { Month } \\
\text { Altitude }\end{array}$ & January & February & March & April & May & June & July & August & September & October & November & December \\
\hline$<3960 \mathrm{~m}$ & 0.41 & 0.12 & 0.21 & 0.00 & 0.82 & 0.26 & 0.38 & 0.06 & 0.15 & 0.48 & 0.18 & 0.00 \\
\hline 3960-4120 m & 0.19 & 0.31 & 0.19 & 0.63 & 0.38 & 0.31 & 0.03 & 0.16 & 0.05 & 0.82 & 0.80 & 1.91 \\
\hline $4120-4250 \mathrm{~m}$ & 0.23 & 0.15 & 0.38 & 0.62 & 0.31 & 0.19 & 0.09 & 0.19 & 0.15 & 1.14 & 0.83 & 2.12 \\
\hline $4250-4516 \mathrm{~m}$ & 0.11 & 1.50 & 0.26 & 0.26 & 0.08 & 0.14 & 0.51 & 0.09 & 0.01 & 1.36 & 1.83 & 3.88 \\
\hline 4516-4670 m & 1.03 & 0.39 & 0.39 & 0.65 & 0.39 & 0.32 & 0.16 & 0.32 & 0.67 & 2.43 & 0.99 & 1.55 \\
\hline
\end{tabular}
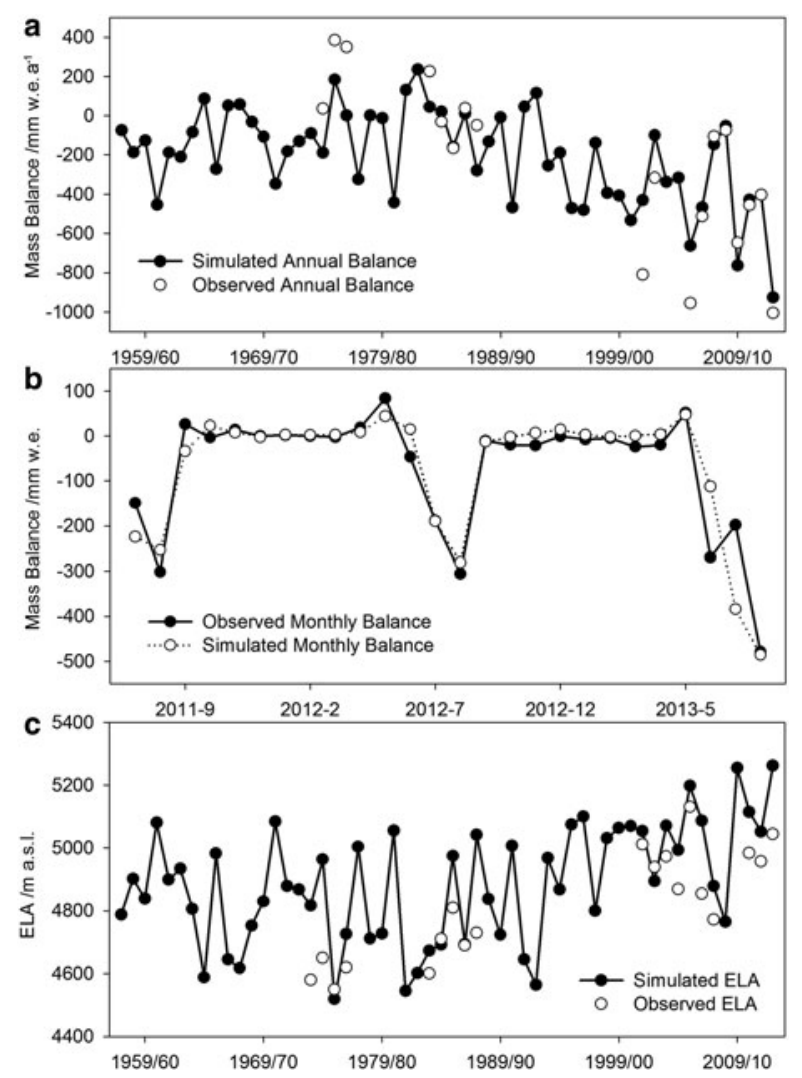

Fig. 2. Observed and simulated annual balance (a), monthly balance (b) and annual ELAs (c) of Qiyi Glacier.

(October-April) were consistent with observations, but some errors occurred in the warm season (May-September). Simulated and observed average monthly balances were, respectively, -69.5 and $-71.5 \mathrm{~mm}$ w.e., with a relative error of $2.8 \%$. Figure $2 \mathrm{c}$ illustrates the comparison between the simulated and observed annual ELAs of Qiyi Glacier. The modeled ELA was consistently higher than the observed ELA, with an average altitude difference of $117 \mathrm{~m}$. Snowdrift from the accumulation area to the firn basin is suspected as the main reason. The snow shift was affected by the special terrain of Qiyi Glacier, so this process was not considered in the model. That is why the modeled mass balance is consistent with observations, but modeled ELA is higher. In general, the model performed moderately well.

\section{RESULTS}

\subsection{Temporal variability of glacier mass balance and ELA}

Mass balance and ELA are both direct and reliable indicators of glacier status. For all 631 investigated glaciers in the Beida
River catchment, the average mass balance for the study period was $-272 \pm 67 \mathrm{~mm}$ w.e. $\mathrm{a}^{-1}(n=56, P<0.001$, $95 \%$ confidence interval), with an ice loss of $3.99 \mathrm{Gt}$ in the last 56 years. The minimum mass balance occurred in $2012 / 13(-1043 \pm 306 \mathrm{~mm}$ w.e. $)$ and the maximum occurred in 1982/83 (197 $\pm 97 \mathrm{~mm}$ w.e.), with a span of $1240 \mathrm{~mm}$ w.e.. Correspondingly, the average ELA was $4916 \pm 55 \mathrm{~m}$ a.s.l. $\mathrm{a}^{-1}(n=56, P<0.001,95 \%$ confidence interval). The highest average ELA occurred in 2012/13 (5280 $\pm 162 \mathrm{~m}$ a.s.l.) and the lowest ELA occurred in 1982/ $83(4292 \pm 276 \mathrm{~m}$ a.s.I.), with a span of $988 \mathrm{~m}$. In the Fengle River, Hongshui River and Tuolai River catchments, the average mass balances were, respectively, $-450 \pm 77$, $-260 \pm 66$ and $-252 \pm 66 \mathrm{~mm}$ w.e. $\mathrm{a}^{-1}(n=56, P<0.001$, $95 \%$ confidence interval), which increased gradually from east to west. Correspondingly, the average ELA of these three catchments was $4894 \pm 48,4923 \pm 57$ and $4916 \pm 55$ $\mathrm{m}$ a.s.l. $\mathrm{a}^{-1}(n=56, P<0.001,95 \%$ confidence interval), respectively.

Figure 3 illustrates the interannual variations in mass balance and ELA. Over the whole simulated period, the mass balance for the Beida River catchment decreased with a trend of $-7.6 \mathrm{~mm}$ w.e. $\mathrm{a}^{-2}$. Accumulated anomalies of annual balance first showed a wavelike increasing trend then decreased sharply, and the maximum occurred in 1992/93. Annual balance varied tremendously before and after 1992/93, and the average mass balance reduced from -161 to $-479 \mathrm{~mm}$ w.e. $\mathrm{a}^{-1}$. The interannual variations in mass balance for the Fengle River, Hongshui River and Tuolai River catchments were similar, with reduction rates of $9.5,7.5$ and $7.3 \mathrm{~mm}$ w.e. $\mathrm{a}^{-2}$, respectively. Correspondingly, ELA rose by $242 \mathrm{~m}$ in the last 56 years, at a rate of $4.3 \mathrm{~m} \mathrm{a}^{-1}$. Additionally, similar change rates of ELA were found for the sub-catchments, which were 4.2, 4.6 and $4.2 \mathrm{~m} \mathrm{a}^{-1}$ for the Fengle River, Hongshui River and Tuolai River catchments, respectively.

Under the dominance of the Indian monsoons and westerlies, the seasonal variation in mass balance for glaciers in western China is distinctive (Yao and others, 2012; Mölg and others, 2014). The warm season (May-September) dominates both ablation and accumulation for glaciers in the Beida River catchment (Fig. 4). Mass balance was slightly positive in the cold season (October-April), with an average of $7.1 \mathrm{~mm}$ w.e.. Ablation and accumulation over this period were both weak. The average monthly ablation was $2.4 \mathrm{~mm}$ w.e., while the monthly accumulation was $9.4 \mathrm{~mm}$ w.e.. Precipitation in the warm season (MaySeptember) accounted for $80 \%$ of the annual total. However, the maximum accumulation occurred in June, rather than July or August. Snowfall during the summer could, with warming, fall as rain and the decrease in fresh snow would then reduce the glacier surface albedo, 

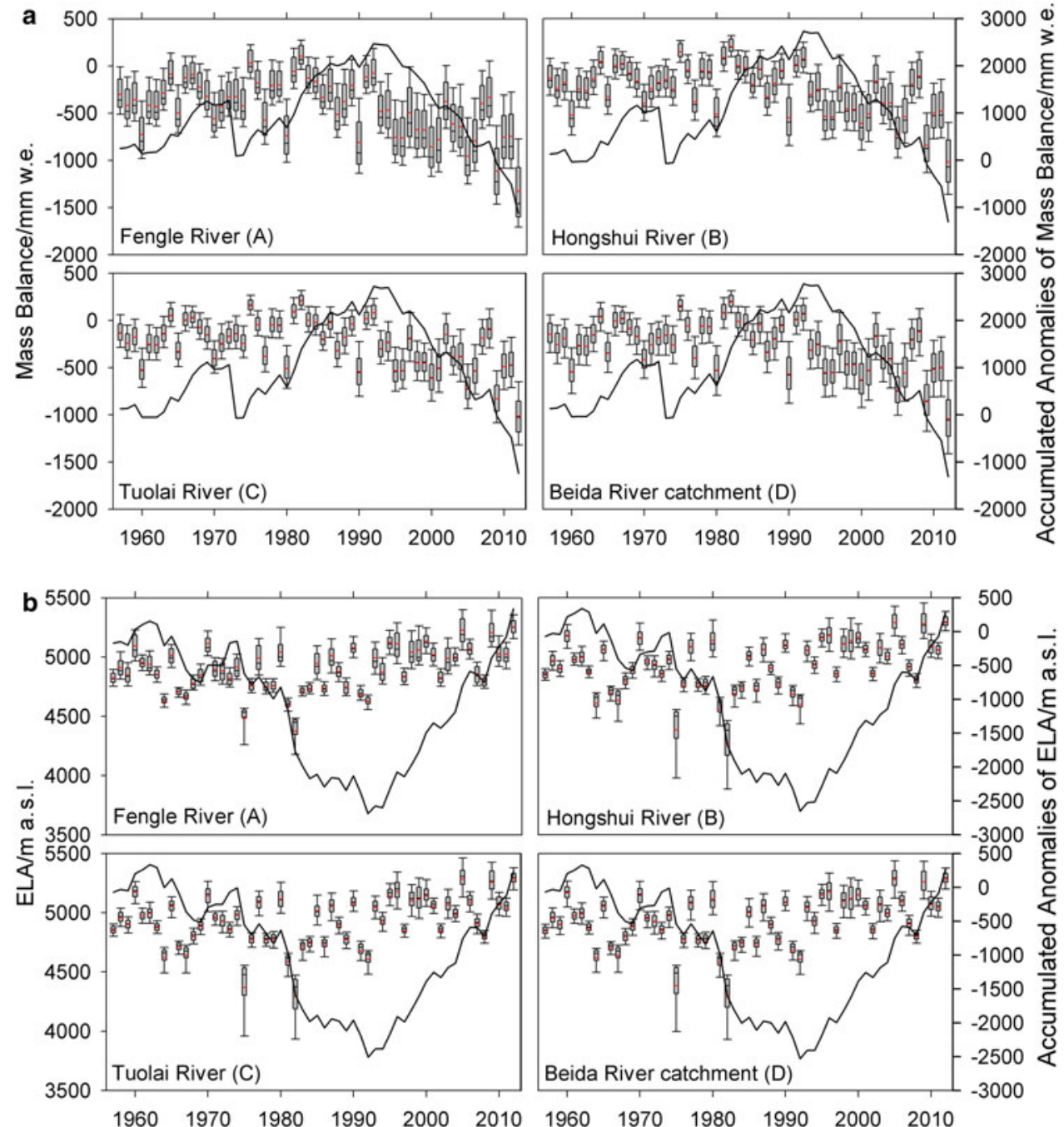

Fig. 3. Interannual variations (box figure) and accumulated anomalies (solid line) in glacier mass balance (a) and ELA (b) for the Beida River catchment. For each year, the horizontal red bar represents the annual average of the sample, Box-and-whisker plots indicate the 10th and 90th percentiles (whisker caps), 25th and 75th percentiles (gray box ends), and median (solid middle bar).

leading to greater ablation (Fujita and Ageta, 2000; Fujita, 2008). Controlled by high temperature, ablation is most intense in July and August, with an average monthly ablation of $226.4 \mathrm{~mm}$ w.e.. The mass balance in May is the most positive because of the reduced ablation and moderate accumulation. Seasonal changes of mass balance in the three sub-

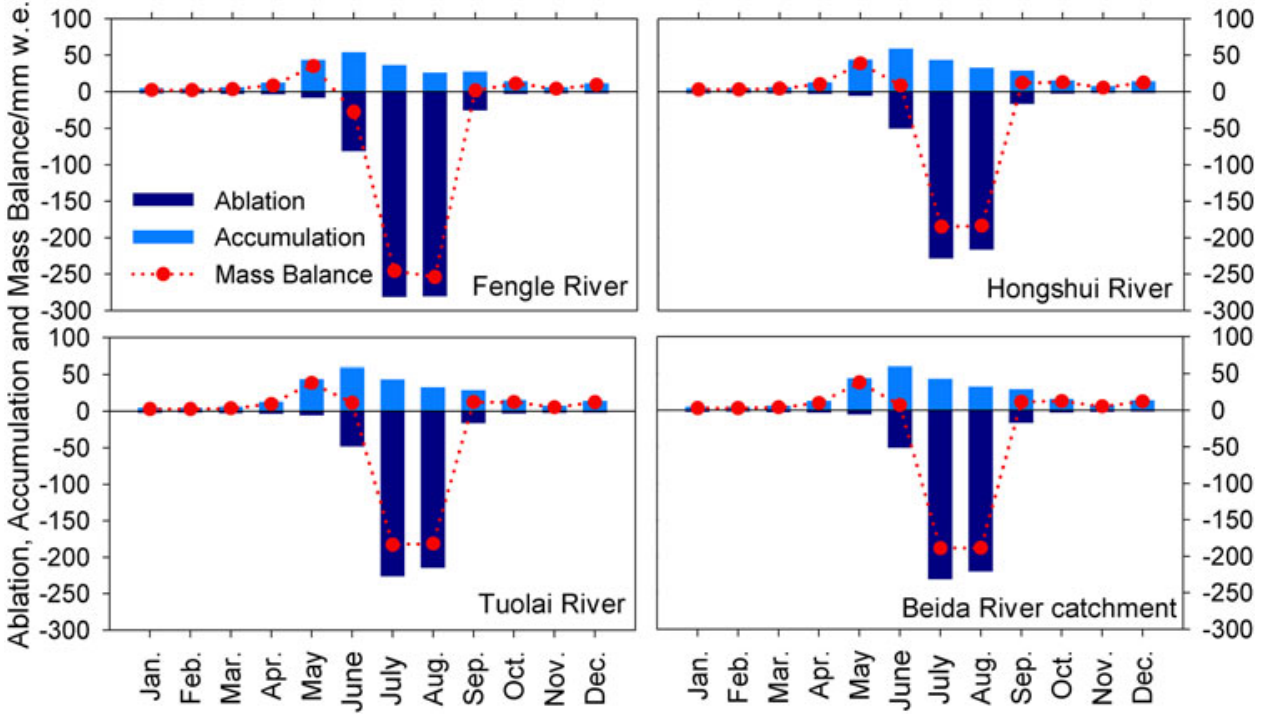

Fig. 4. Seasonal changes of ablation, accumulation and mass balance for glaciers in Beida River catchment. 
catchments were similar to those of the Beida River catchment. Seasonal changes of mass balance were controlled by summer (June, July and August) temperature and the warm season (May-September) precipitation.

\subsection{Spatial variability of the mass balance and ELA}

To investigate the spatial variability of mass balance and ELA for glaciers in the Beida River catchment, glacier distribution was classified into 11 latitude intervals $\left(0.1^{\circ}\right)$ and 10 longitude intervals $\left(0.2^{\circ}\right.$; Fig. 5). There is no clear trend with latitude (Fig. 5a). On the other hand, both mass balance and ELA decreased gradually with longitude from west to east. Mass balance changed $312 \mathrm{~mm}$ w.e. per degree of longitude, and the equivalent variation of ELA was $73 \mathrm{~m}$.

\section{DISCUSSION}

\subsection{Reasons for variations of mass balance and ELA}

\subsubsection{The role of climate control}

To explore the effect of climate control on glaciers around the study area, the annual air temperature and precipitation from meteorological stations were selected to analyze abrupt change, trend and persistence (Table 5, Fig. 6). Then, massbalance sensitivities to climatic control were assessed.

Abrupt changes in the time series were analyzed by using the Mann-Kendall method (Hirsch and Slack, 1984; Wei, 2008), which is a non-parametric statistical test method. The
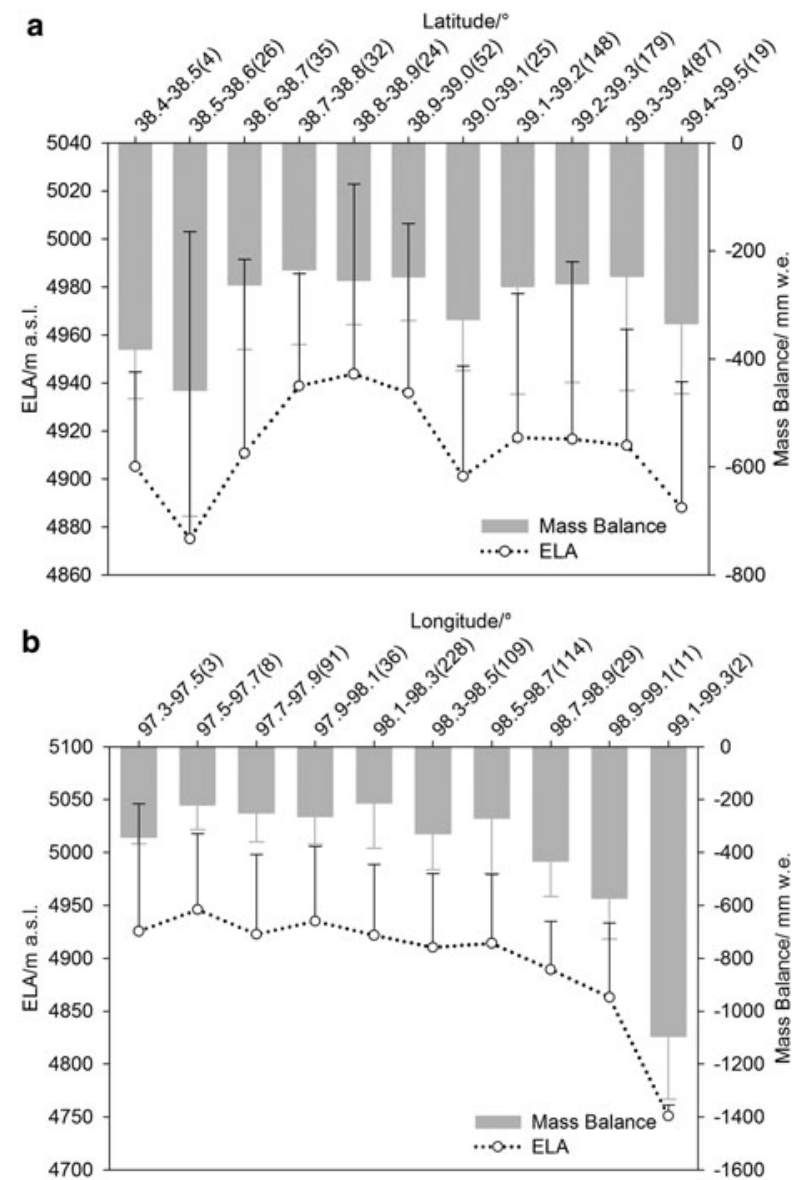

Fig. 5. Spatial variability of glacier mass balance and ELA (the number in brackets is the number of glaciers in each interval, similarly hereinafter).

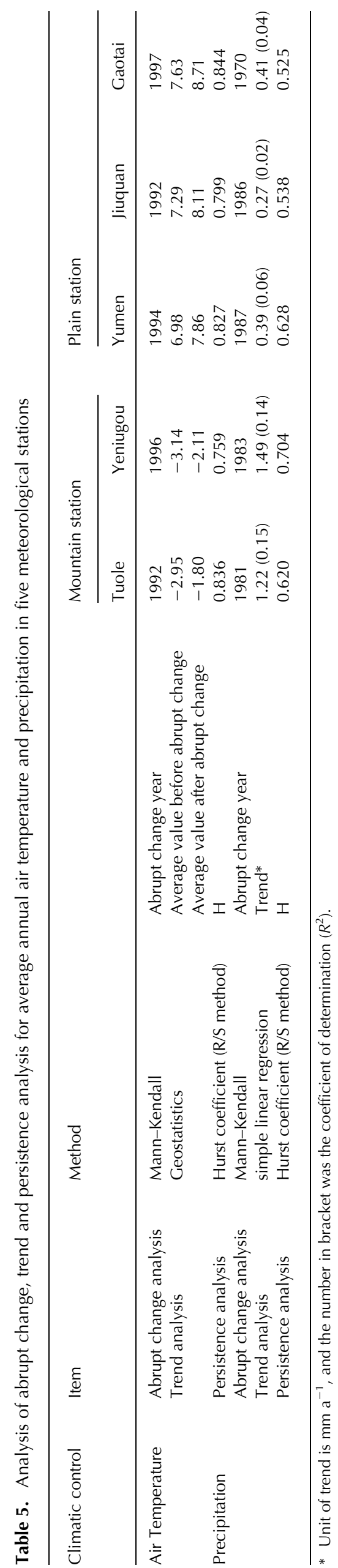



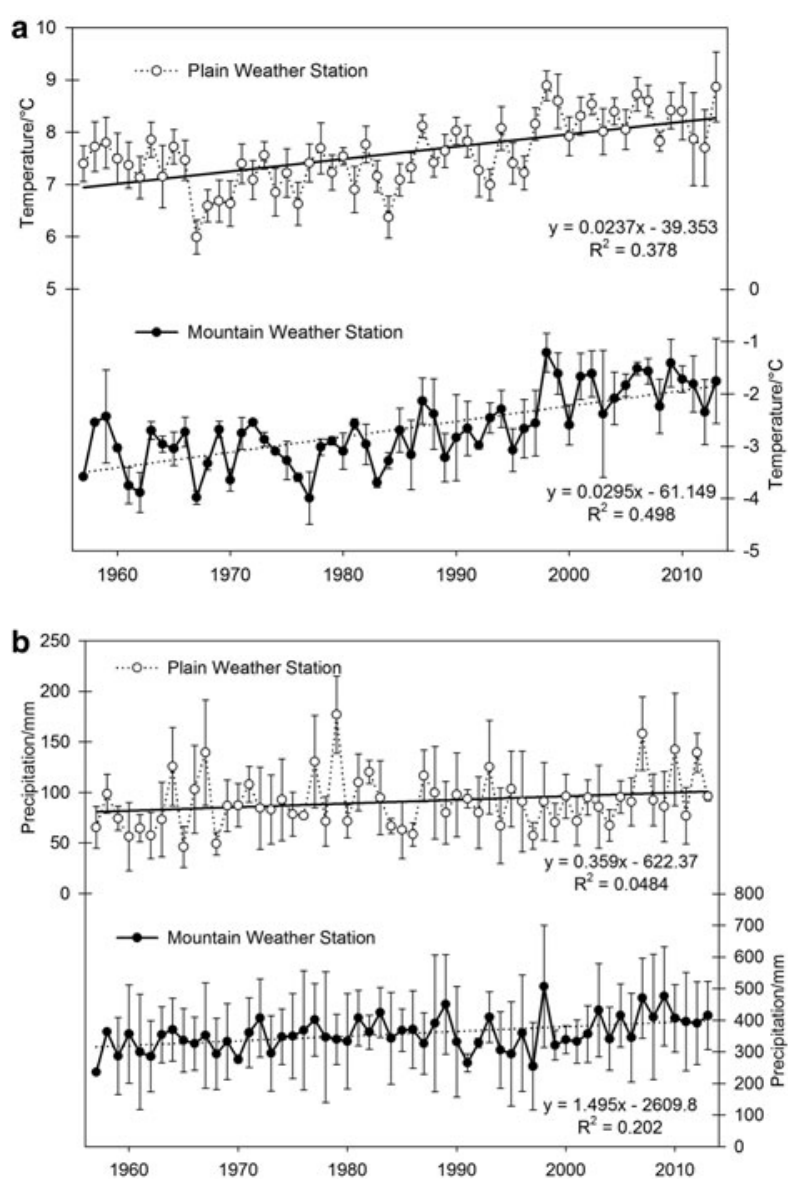

Fig. 6. Average annual air temperature (a) and precipitation (b) in mountain and plain meteorological stations.

results show an abrupt change of annual air temperature happened in the middle of the 1990s, and temperature continued to rise thereafter. Especially after 2000, the significance level of the warming trend vastly exceeded the 0.05 threshold value $\left(\alpha_{0.05}= \pm 1.96\right)$; thus, the warming trend was quite significant. Climate change was different between mountains and plains. The temperature difference in the mountain stations before and after the abrupt change year was $1.09^{\circ} \mathrm{C}$, and $0.93^{\circ} \mathrm{C}$ in the plains stations. Assuming a continuous linear trend, the average annual air temperature rose by $0.295^{\circ} \mathrm{C}(10 \mathrm{a})^{-1}$ in the mountains, compared with $0.237^{\circ} \mathrm{C}(10 \mathrm{a})^{-1}$ in the plains. An abrupt change of annual precipitation happened in the early 1980s in the mountains, but in the middle of the 1980s in the plains (1970 at Gaotai station). Whether in the mountains or in the plains, the series had a non-significant increasing trend, with the growth rates of $15 \mathrm{~mm}(10 \mathrm{a})^{-1}$ in the mountains and $3.6 \mathrm{~mm}(10 \mathrm{a})^{-1}$ in the plains.

Long-range dependence generally existed in the climatic time series. The Hurst coefficient $(\mathrm{H}, \mathrm{O}<\mathrm{H}<1)$ was used for quantitatively describing this long-range dependence, namely, persistence. The R/S method is one of the most common methods to estimate the Hurst coefficient (Rao and Bhattacharya, 1999). The results showed all Hurst coefficients exceeded 0.5 (Table 5), which indicated the trend of the climatic time series had a strong persistence. The Hurst coefficients for annual temperature all exceeded 0.75 , while they were only $0.5-0.7$ for precipitation. Thus, warming and wetting would continue in the future. Compared with precipitation, the persistence of air temperature was stronger.
Mass-balance sensitivities refer to variations in mass balance caused by instantaneous changes in temperature and precipitation. Combined with the data on anomalies of temperature $(\Delta T)$ and precipitation $(\Delta P)$ in mountain meteorological stations, glacier mass change $(\Delta B)$ in the Beida River catchment over any given period can be computed by:

$$
\Delta B=\frac{\partial B}{\partial T} \Delta T+\frac{\partial B}{\partial P} \Delta P
$$

where $\partial B / \partial T$ and $\partial B / \partial P$ are mass-balance sensitivities to temperature and precipitation change, respectively.

In the study area, the mass-balance sensitivities to temperature and precipitation change were, respectively, $-239 \mathrm{~mm}$ w.e. ${ }^{\circ} \mathrm{C}^{-1} \mathrm{a}^{-1}$ and $+1.1 \mathrm{~mm}$ w.e. $\mathrm{mm}^{-1} \mathrm{a}^{-1}$. That is, a $210 \mathrm{~mm}$ increase in precipitation was needed to compensate for the net mass loss induced by an air temperature increase of $1^{\circ} \mathrm{C}$. According to the recent rates of increase

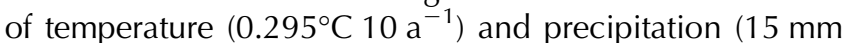
$\left.10 \mathrm{a}^{-1}\right)$, the glacier mass balance in the Beida River catchment will reach $-463 \mathrm{~mm}$ w.e. in the 2020s, and -627 $\mathrm{mm}$ w.e. in the 2050 s.

\subsubsection{The role of glacial morphological variables}

With the warming and wetting in the Beida River catchment, glacier areas have varied considerably. The total area of the 631 investigated glaciers decreased from 318.2 to $275.3 \mathrm{~km}^{2}$, with a loss of $13.5 \%$ during 1970-2000. Thirteen glaciers, with a total area of $1.02 \mathrm{~km}^{2}$, had disappeared completely by 2000. Three new glaciers appeared by fragmentation of older ones. Glacial morphological variables played an important role in the variations of glacier mass balance and ELA. Mountain regions dominated by small glaciers are generally more sensitive to change (Bahr and others, 1998). Figure 7 presents the relationship between mass balance (ELA) and initial glacier size (1970s) for 631 glaciers in the Beida River catchment. All 631 glaciers were classified into six size classes $(<0.1,0.1-0.5,0.5-1,1-2$, $2-5$ and $>5 \mathrm{~km}^{2}$ ). The mass balance was more negative for small glaciers $\left(<2 \mathrm{~km}^{2}\right)$, and the mean was $-254 \pm 221$, $-279 \pm 183,-286 \pm 153$ and $-260 \pm 147 \mathrm{~mm}$ w.e. in the $<0.1, \quad 0.1-0.5,0.5-1$ and $1-2 \mathrm{~km}^{2}$ intervals, respectively. Mass balance increased when area exceeded $2 \mathrm{~km}^{2}$, and the average mass balance was $-192 \pm 74$ and $-165 \pm 142 \mathrm{~mm}$ w.e. in the $2-5$ and $>5 \mathrm{~km}^{2}$ intervals, respectively. The ELA increased linearly with glacier area, at a rate of $9.2 \mathrm{~m} \mathrm{~km}^{-2}$.

\subsubsection{The role of topographic variables}

Mass balance increased linearly with altitude, at a rate of $128.7 \mathrm{~mm}$ w.e. $(100 \mathrm{~m})^{-1}$. Correspondingly, the trend of ELA with altitude presented first a rise then a drop instead of a monotonicity, and the highest average ELA was $4937 \mathrm{~m}$ a.s.I. in the $4700-4800 \mathrm{~m}$ interval (Fig. 8a). $90.6 \%$ of the glaciers had an average slope between $20^{\circ}$ and $35^{\circ}$. Mass balance and ELA were similar in all six intervals except the $10^{\circ}-15^{\circ}$ interval. The difference between maximum and minimum of mass balance was $64 \mathrm{~mm}$ w.e., and $55 \mathrm{~m}$ of ELA (Fig. 8b). Among the eight aspects of glaciers (Fig. 8c), 501 glaciers faced north (north, northeast and northwest), accounting for $79.4 \%$ of the total number. The most negative mass balances, appearing in glaciers of these three aspects, were $-412,-315$ and $-277 \mathrm{~mm}$ w.e., respectively. On the contrary, only $9 \%$ of the glaciers faced south, with an average mass balance 

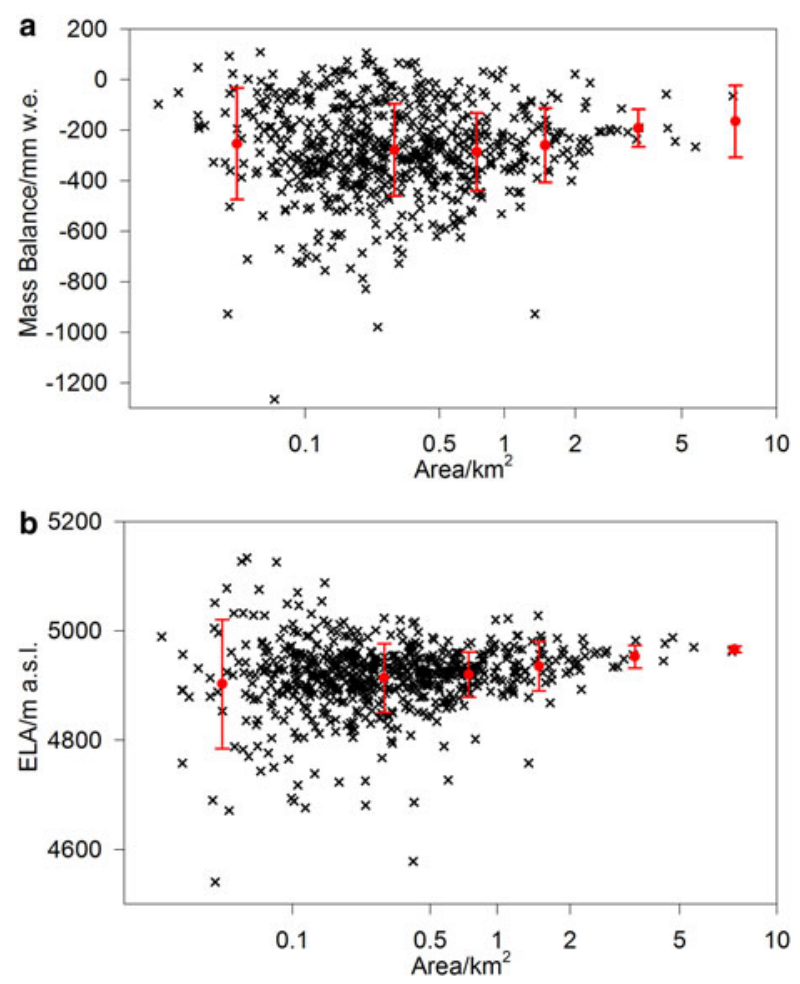

Fig. 7. Relationships between initial glacier size (1970s) and mass balance (a) and ELA (b). Average values of glacier mass balance or ELA (red point) together with uncertainty ranges (whisker caps) are shown for six area classes $(<0.1,0.1-0.5,0.5-1,1-2,2-5$ and $\left.>5 \mathrm{~km}^{2}\right)$.

of $-28 \mathrm{~mm}$ w.e.. Average ELAs in all aspects were between 4860 and $4940 \mathrm{~m}$ a.s.l., and glaciers facing south and west had lower ELAs than glaciers facing north and east.

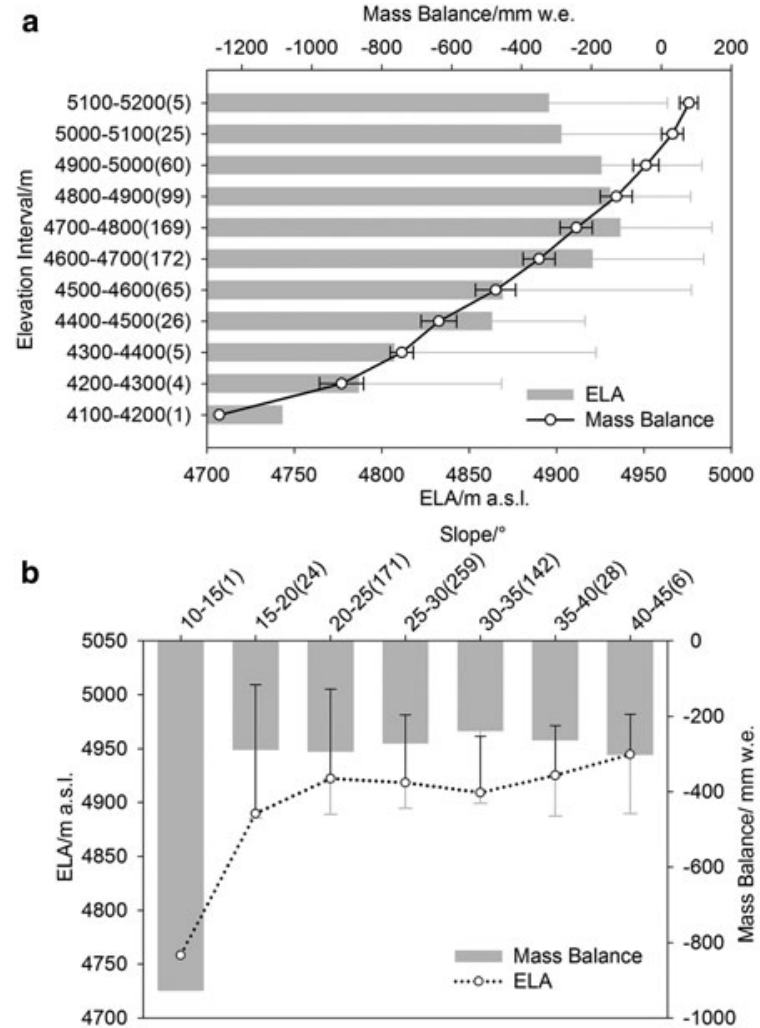

\subsection{The relationship between mass balance and ELA}

An excellent linear relationship (Fig. 9) existed between annual mass balance $(B)$ and ELA $\left(E L A_{t}\right.$ for the same year $(t)$, Braithwaite (1984) described this relationship as:

$$
B_{\mathrm{t}}=\alpha\left(E L A_{0}-E L A_{\mathrm{t}}\right)
$$

where $E L A_{0}$ is the balanced-budget ELA, i.e., when $B_{\mathrm{t}}=0$, $E L A_{\mathrm{t}}=E L A_{0}$; and $\alpha$ is termed the effective balance gradient, as it represents a type of time- and space-average of the balance gradient. Regarding all 631 investigated glaciers in the Beida River catchment as a whole, the balanced-budget ELA ( $\left.E L A_{0}\right)$ was $4687 \mathrm{~m}$ a.s.l., and the effective balance gradient $(\alpha)$ was $113.5 \mathrm{~mm}$ w.e. $(100 \mathrm{~m})^{-1}$. The effective balance gradient obviously changed in 2005/06, 2009/10 and 2012/13 (Fig. 9) when the mass balances $(-745,-860$ and $-1043 \mathrm{~mm}$ w.e.) were the most negative. The reason was that the annual ELAs (5279, 5260 and $5280 \mathrm{~m}$ a.s.l.) in these 3 years had exceeded the top of $96.8 \%$ of the investigated glaciers.

\subsection{Glacier meltwater runoff and potential effect on surface runoff}

The average annual river runoff in the Beida River catchment was $9.74 \times 10^{8} \mathrm{~m}^{3}$, and glacier meltwater runoff was $1.51 \times$ $10^{8} \mathrm{~m}^{3}$, accounting for $15.2 \%$ of surface runoff (Table 6 ). Only the contribution in the Fengle River catchment was similar to that of the Beida River catchment. In the other two sub-catchments, the average annual glacier meltwater runoff was almost the same, but there was a difference in the roles of glaciers in supplying rivers. In the Hongshui River catchment, more than $1 / 4$ of the surface runoff was derived from meltwater, while the proportion was only $\sim 1$ / 10 in the Tuolai River catchment.

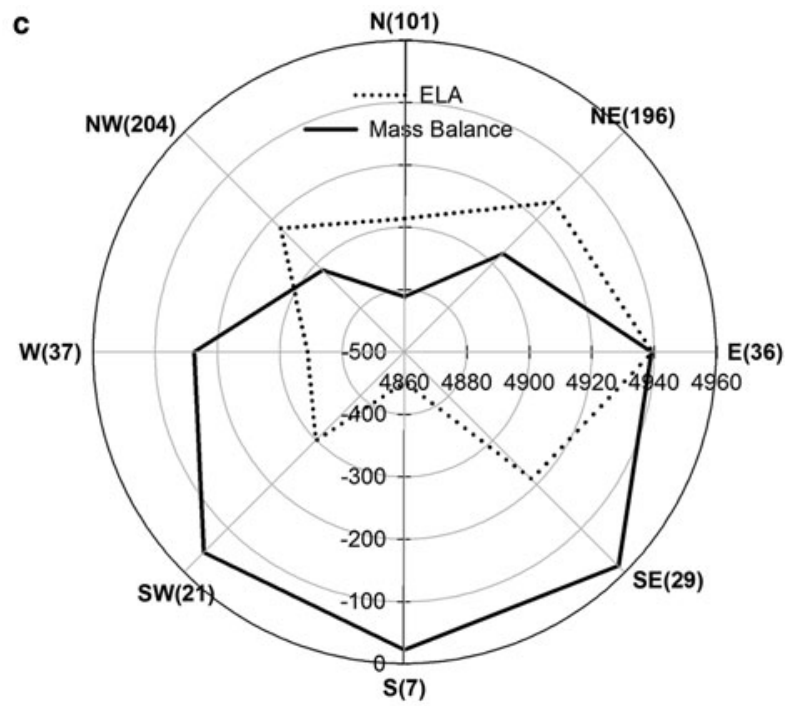

$$
\text { 害 }
$$

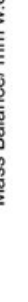

Fig. 8. Relationships between mass balance and ELA and average altitude (a), slope (b) or aspects (c) of glaciers in the Beida River catchment. 


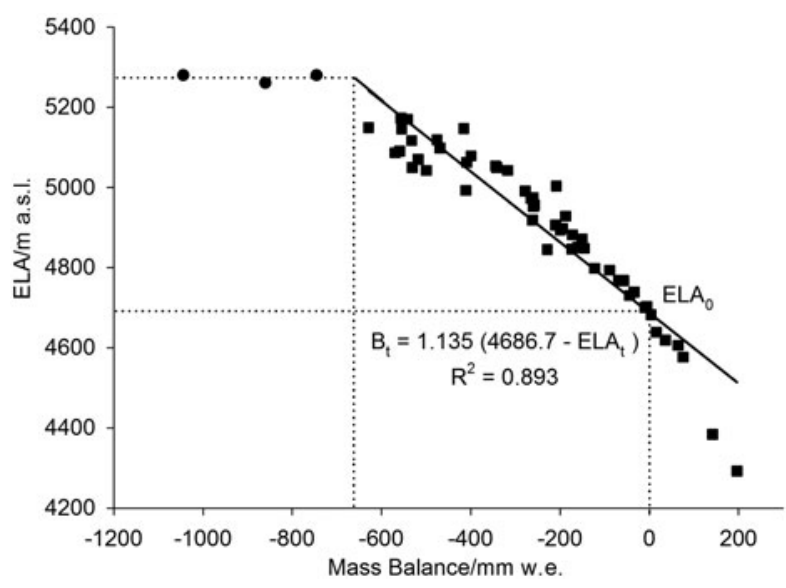

Fig. 9. Relationship between annual mass balance and ELA.

Table 6. Average annual river runoff, glacier meltwater runoff and contribution during 1957-2013

\begin{tabular}{|c|c|c|c|c|}
\hline & \multicolumn{3}{|c|}{ Sub-catchment } & \multirow{2}{*}{$\begin{array}{l}\text { Beida River } \\
\text { catchment }\end{array}$} \\
\hline & Fengle & Hongshui & Tuolai & \\
\hline $\begin{array}{l}\text { Glacier meltwater } \\
\text { runoff }\left(10^{8} \mathrm{~m}^{3}\right)\end{array}$ & 0.16 & 0.67 & 0.68 & 1.51 \\
\hline River runoff $\left(10^{8} \mathrm{~m}^{3}\right)$ & 0.98 & 2.51 & 6.25 & 9.74 \\
\hline Contribution (\%) & 16.2 & 26.3 & 10.6 & 15.2 \\
\hline
\end{tabular}

As to the seasonal distribution (Fig. 10), meltwater runoff and surface runoff in the Beida River catchment were both concentrated in summer, especially in July and August. Seasonal variation presented a unimodal distribution, because high temperatures in summer dominated glacier ablation, and precipitation in summer accounted for $2 / 3$ of annual precipitation.

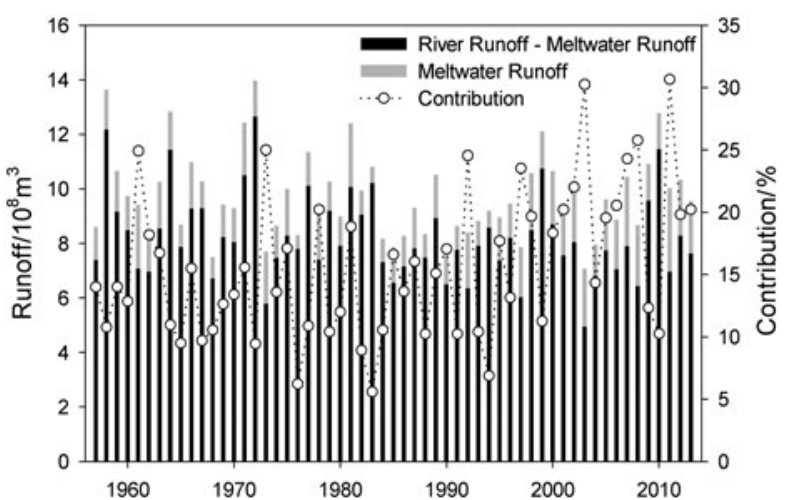

Fig. 11. Annual river runoff, glacier meltwater runoff and its contribution in Beida River catchment during 1957-2013.

In wintertime (from October to March of the following year), meltwater was limited and surface runoff was homogeneous, with an average of $0.378 \times 10^{8} \mathrm{~m}^{3} .92 .3 \%$ of runoff during wintertime was derived from the Tuolai River, which was mainly supplied by base flow, such as spring water (Zhao and others, 2011). In the other two sub-catchments, although limited, the main water supply of runoff during wintertime was still glacier meltwater, and the contribution even exceeded $80 \%$ in some months. Consequently, groundwater was also an important component of the water supply in addition to glaciers and precipitation in Tuolai River catchment.

Figure 11 illustrates the annual river runoff, glacier meltwater runoff and its contribution to the Beida River catchment during 1957-2013. Abrupt change and trend analysis were carried out by using the Mann-Kendall method. The results showed that annual runoff decreased insignificantly, at a rate of $0.011 \times 10^{8} \mathrm{~m}^{3} \mathrm{a}^{-1}$. The time series of glacier meltwater runoff changed abruptly in 2000, and the trend had a transition from a slow decrease to a rapid increase

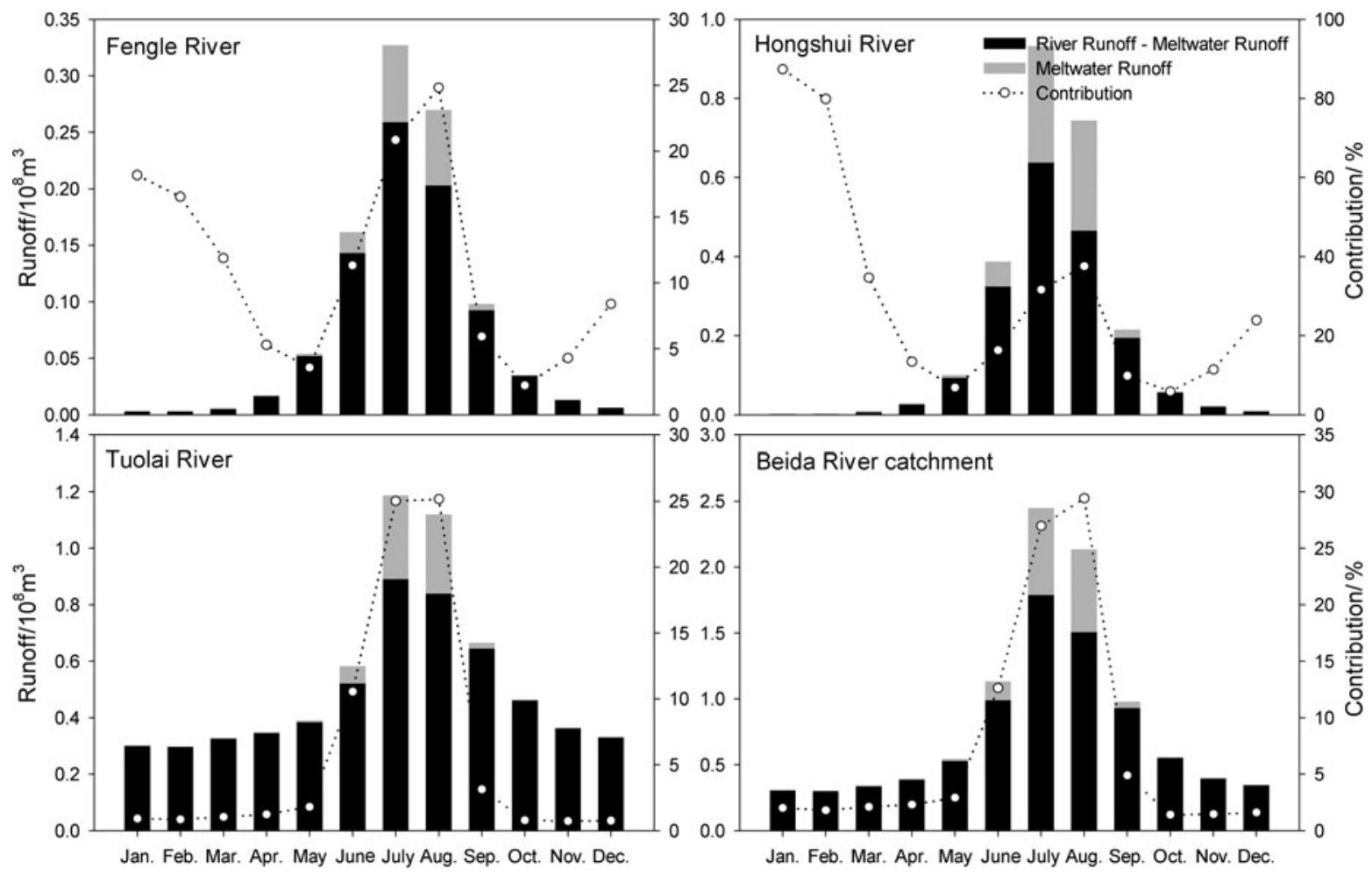

Fig. 10. Average monthly river runoff, glacier meltwater runoff and contribution in the Beida River catchment during 1957-2013. 

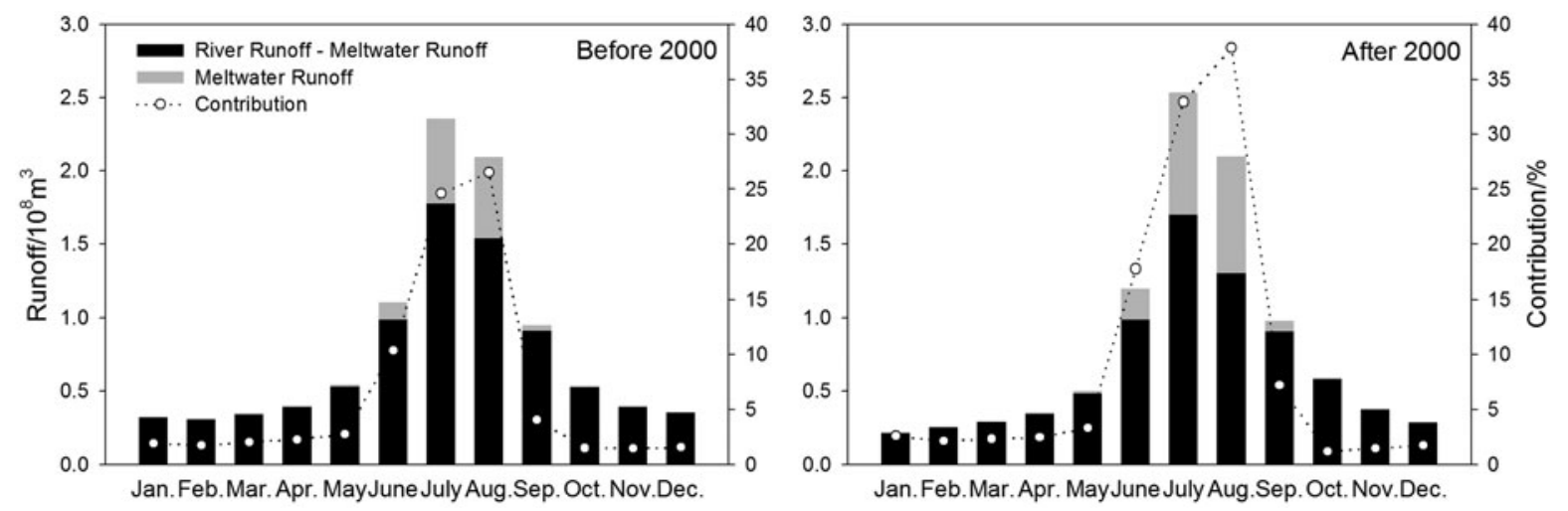

Fig. 12. Average monthly river runoff, glacier meltwater runoff and contribution before and after 2000 in Beida River catchment.

before and after 2000. Average annual meltwater runoff increased from $1.35 \times 10$ to $1.97 \times 10^{8} \mathrm{~m}^{3}$, and the contribution to surface runoff increased from 13.9 to $20.4 \%$. Therefore, the role of glacier meltwater supplying surface runoff was significantly strengthened with climate warming. Although average annual runoff declined slightly by $0.03 \times$ $10^{8} \mathrm{~m}^{3}$ before and after 2000, the composition of runoff in different seasons changed considerably (Fig. 12). Surface runoff was mostly supplied by base flow (spring water) from November to May of the following year (Zhao and others, 2011), but monthly supply decreased by $0.056 \times$ $10^{8} \mathrm{~m}^{3}(14.7 \%)$. Thus the role of groundwater supply was gradually weakened. Surface runoff increased by a total of $0.36 \times 10^{8} \mathrm{~m}^{3}$ from June to October, which was principally caused by the increase of meltwater runoff in summer, with an increment of $0.59 \times 10^{8} \mathrm{~m}^{3}$.

\section{CONCLUSIONS}

Based on in-situ measurements on Qiyi Glacier, in combination with meteorological, hydrological and remote-sensing data, a distributed degree-day model at $1 \mathrm{~d}$ temporal resolution and $90 \mathrm{~m}$ spatial resolution was developed for the 631 investigated glaciers in the Beida River catchment. Utilizing this model, we reconstructed the time series of mass balance and ELA from 1957 to 2013. In parallel, we analyzed the factors that affected glacier mass balance and ELA, and discussed the essential relationships between glaciers and runoff. According to the above study, several facts were worth highlighting:

- The average mass balance was $-272 \pm 67 \mathrm{~mm}$ w.e. $\mathrm{a}^{-1}$, with an ice loss of 3.99 Gt during 1957-2013. Correspondingly, the average ELA was $4916 \pm 55 \mathrm{~m}$ a.s.l. $\mathrm{a}^{-1}$; assuming a continuous linear trend, ELA rose by $242 \mathrm{~m}$.

- Compared with morpho-topographic variables, climatic control is a more important factor affecting glaciers. A $210 \mathrm{~mm}$ increase in precipitation would be needed to compensate for the net mass loss induced by an air temperature increase of $1^{\circ} \mathrm{C}$. Mass balance sensitivity to air temperature change was $-239 \mathrm{~mm}$ w.e. ${ }^{\circ} \mathrm{C}^{-1} \mathrm{a}^{-1}$, while sensitivity to precipitation change was $+1.1 \mathrm{~mm}$ w.e. $\mathrm{mm}^{-1} \mathrm{a}^{-1}$.

- The average annual runoff was $9.74 \times 10^{8} \mathrm{~m}^{3}$ in the Beida River catchment during 1957-2013, and glacier meltwater runoff was $1.51 \times 10^{8} \mathrm{~m}^{3}$, accounting for $15.2 \%$ of runoff. Series of annual meltwater runoff changed abruptly in 2000, and the contribution to runoff increased from 13.9 to $20.4 \%$ before and after 2000 .
- Glacier meltwater and runoff were both concentrated in summer. Seasonal variation presented a unimodal distribution. With climate warming, the supply of meltwater was significantly increased in summer, with an increase of $0.59 \times 10^{8} \mathrm{~m}^{3}$. The base flow, a dominating water supply in wintertime, had a gradually weakened role in supplying runoff.

\section{ACKNOWLEDGEMENTS}

This research was funded by the National Natural Science Foundation of China (No. 41190081; No. 41171056) and the Strategic Priority Research Program (B) of CAS (grant XDB03030208). We thank Zhang Huawei for providing topographical maps of the Beida River catchment, and all members of expedition in Qiyi Glacier from 2010 to 2012.

\section{REFERENCES}

Arendt AA, Echelmeyer KA, Harrison WD, Lingle CS and Valentine VB (2002) Rapid wastage of Alaska glaciers and their contribution to rising sea level. Science, 297(5580), 382-386 (doi: 10.1126/science.1072497)

Arnold NS, Willis IC, Sharp MJ, Richards KS and Lawson WJ (1996) A distributed surface energy- balance model for a small valley glacier. I. Development and testing for Haut Glacier d'Arolla, Valais, Switzerland. J. Glaciol., 42, 77-89

Azam MF and 5 others (2014) Reconstruction of the annual mass balance of Chhota Shigri glacier, Western Himalaya, India, since 1969. Ann. Glaciol., 55(66), 69-80 (doi: 10.3189/2014AoG66A104)

Bahr DB, Pfeffer WT, Sassolas C and Meier MF (1998) Response time of glaciers as a function of size and mass balance: 1 . Theory. J. Geophys. Res., 103(B5), 9777-9782 (doi: 10.1029/98JB00507)

Bolch T and 11 others (2012) The state and fate of Himalayan glaciers. Science, 336(6079), 310-314 (doi: 10.1126/science.1215828)

Braithwaite (1984) Can the mass balance of a glacier be estimated from its equilibrium line altitude? J. Glaciol., 30(106), 364-368

Braithwaite RJ and Zhang Y (2000) Sensitivity of mass balance of five glaciers to temperature changes assessed by tuning a degree-day model. J. Glaciol., 46(152), 7-14

Brock BW and Arnold NS (2000) A spreadsheet-based (Microsoft Excel) point surface energy balance model for glacier and snow melt studies. Earth. Surf. Proc. Land, 25(6), 649-658 (doi: 10.1002/1096-9837(200006)25:6<649::AID-ESP97>3.0. $\mathrm{CO} ; 2-\mathrm{U})$

Fujita K (2008) Effect of precipitation seasonality on climatic sensitivity of glacier mass balance. Earth Planet. Sc. Lett., 276, 1419 (doi: 10.1016/j.epsl.2008.08.028)

Fujita K and Ageta Y (2000) Effect of summer accumulation on glacier mass balance on the Tibetan Plateau revealed by mass- 
balance model. J. Glaciol., 46(153), 244-252 (doi: 10.3189/ 172756500781832945)

Gao TG and 6 others (2015) Simulation and analysis of glacier runoff and mass balance in the Nam Co basin, southern Tibetan Plateau. J. Glaciol., 61(227), 447-460 (doi: 10.3189/ 2015JoG14J170)

Gardner AS and 15 others (2013) A reconciled estimate of glacier contributions to sea level rise: 2003 to 2009. Science, 340 (6134), 852-857 (doi: 10.1126/science.1234532)

Giesen RH and Oerlemans J (2013) Climate-model induced differences in the 21 st century global and regional glacier contributions to sea-level rise. Clim. Dyn., 41(11-12), 3283-3300 (doi: 10.1007/s00382-013-1743-7)

Hirsch RM and Slack JR (1984) A nonparametric trend test for seasonal data with serial dependence. Water Resour. Res., 20(6), 727-732 (doi: 10.1029/WR020i006p00727)

Hock R (1999) A distributed temperature-index ice- and snowmelt model including potential direct solar radiation. J. Glaciol., 45 (149), 101-111

Hock R (2003) Temperature index melt modelling in mountain regions. J. Hydrol., 282(1-4), 104-115 (doi: 10.1016/S00221694(03)00257-9)

Jóhannesson T, Sigurdsson O, Laumann T and Kennett M (1995) Degreeday glacier mass-balance modeling with applications to glaciers in Iceland, Norway and Greenland. J. Glaciol., 41(151), 345-358

Kang ES, Cheng GD, Lan YC and Jin HJ (1999) Runoff response to climate change model in continental river basins in arid zones of northwest China. Sci. China (Ser. D), 29(S1), 47-54 [in Chinese]

Kaser G (1999) A review of the modern fluctuations of tropical glaciers. Global Planet. Change, 22, 93-103 (doi: 10.1016/S09218181(99)00028-4)

Kaser G, Cogley JG, Dyurgerov MB, Meier MF and Ohmura A (2006) Mass balance of glaciers and ice caps: consensus estimates for 1961-2004. Geophys. Res. Lett., 33(19), L19501 (doi: 10.1029/ 2006GL027511)

Liu Q and Liu SY (2016) Response of glacier mass balance to climate change in the Tianshan Mountains during the second half of the twentieth century. Clim. Dynam., 46(1-2), 303-316 (doi: 10.1007/s00382-015-2585-2)

Liu CH, Xie ZC and Yang HA (1992) Observation, interpolation and trend study of glacier mass balance on the Qiyi Glacier in Qilian Mountain. Science Press, Beijing, 21-33 [in Chinese]

Liu SY, Ding YJ and Zhang Y and others (2006) Impact of the glacial change on water resources in the Tarim River Basin. J. Geogr. Sci., 61, 482-490 [in Chinese]

Marzeion B, Jarosch AH and Hofer M (2012) Past and future sealevel change from the surface mass balance of glaciers. Cryosphere, 6, 1295-1322 (doi: 10.5194/tc-6-1295-2012)

Meier MF (1984) Contribution of small glaciers to global sea level. Science, 226(4681), 1418-1421 (doi: 10. 1126/ science.226.4681.1418)

Meier MF and 7 others (2007) Glaciers dominate Eustatic sea-level rise in the 21st century. Science, 317(5841), 1064-1067 (doi: 10.1126/science.1143906)

Mölg T, Cullen NJ, Hardy DR, Kaser G and Klok L (2008) Mass balance of a slope glacier on Kilimanjaro and its sensitivity to climate. Int. J. Climatol., 28, 881-892

Mölg T, Maussion F and Scherer D (2014) Mid-latitude westerlies as a driver of glacier variability in monsoonal High Asia. Nat. Clim. Change, 4, 68-73. (doi: 10.1038/NCLIMATE2055)

Oerlemans J (1992) Climate sensitivity of glaciers in southern Norway: application of an energy-balance model to Nigardsbreen, Hellstugubreen and Alfotbreen. J. Glaciol., 38, 223-232

Oerlemans J and Fortuin JPF (1992) Sensitivity of glaciers and small ice caps to greenhouse warming. Science, 258(5079), 115-117 (doi: 10.1126/science.258.5079.115)
Oerlemans J and Knap WH (1998) A 1 year record of global radiation and albedo in the ablation zone of Morteratschgletscher Switzerland. J. Glaciol., 44, 231-238

Paul F, Kääb A, Maisch M, Kellenberger T and Haeberli W (2004) Rapid disintegration of Alpine glaciers observed with satellite data. Geophys. Res. Lett., 31(21), L21402 (doi: 10.1029/2004GL020816)

Pellicciotti $\mathrm{F}$ and 5 others (2005) An enhanced temperature-index glacier melt model including the shortwave radiation balance: development and testing for Haut Glacier d'Arolla, Switzerland. l. Glaciol., 51, 573-587 (doi: 10.3189/172756505781829124)

Pu JC and 5 others (2005) Mass balance of the Qiyi glacier in the Qilian mountains: a new observation. J. Glaciol. Geocryol., 27, 199-206 [in Chinese]

Radić V and Hock R (2011) Regional differentiated contribution of mountain glaciers and ice caps to future sea level rise. Nat. Geo., 4, 91-94 (doi: 10.1038/NGEO1052)

Raper SCB and Braithwaite RJ (2006) Low sea level rise projections from mountain glaciers and icecaps under global warming. Nature, 439, 311-313 (doi: 10.1038/nature04448)

Rao AR and Bhattacharya D (1999) Hypothesis testing for long-term memory in hydrologic series. J. Hydrol., 216, 183-196 (doi: 10.1016/S0022-1694(99)00005-0)

Sicart JE, Hock R, Ribstein P, Litt M and Ramirez E (2011) Analysis of seasonal variations in mass balance and meltwater discharge of the tropical Zongo Glacier by application of a distributed energy balance model. J. Geophys. Res., 116, D13105 (doi: 10.1029/2010JD015105)

Shi YF and Zhang XS (1995) The impact of climate change on surface water resources in arid areas of Northwest China and the future trends. Sci. China (Ser B), 25, 968-977 [in Chinese]

Slangen ABA and 5 others (2016) Anthropogenic forcing dominates global mean sea-level rise since 1970. Nat. Clim. Change, 6(7), 701-705 (doi: 10.1038/NCLIMATE2991)

Viviroli D, Dürr HH, Messerli B, Meybeck M and Weingartner R (2007) Mountains of the world, water towers for humanity: typology, mapping, and global significance. Water Resour. Res., 43, W07447 (doi: 10.1029/2006WR005653)

Wang ZX, Xie ZC and Wu GH (1984) Glacier mass balance in Qilian Mountain. Science Press, Beijing, 41-53 [in Chinese]

Wang GX, Li Q and Chen GD and others (2001) Climate change and its impact on the eco-environment in the source regions of the Yangtze and Yellow Rivers in recent 40 years. J. Glaciol. Geocryol., 23, 346-352 [in Chinese]

Wang NL and 6 others (2009) Study on the zone of maximum precipitation in the north slopes of the central Qilian Mountains. J. Glaciol. Geocryol., 31(3), 395-403 [in Chinese]

Wang S, Pu JC and Wang NL (2011) Study on mass balance and sensibility to climate change in summer on the Qiyi Glacier Qilian Mountains. J. Glaciol. Geocryol., 33, 1214-1221 [in Chinese]

Wei FY (2008) Statistical diagnosis and predicted technology for modern climate, 2nd edn. China Meteorological Press, Beijing, 1-296 [in Chinese]

Yang JP, Ding YJ and Shen YP and others (2004) Climatic features of ecoenvironment change in the source regions of the Yangtze and Yellow Rivers in recent 40 years. J. Glaciol. Geocryol., 26, 7-16 [in Chinese]

Yang W and 5 others (2013) Mass balance of a maritime glacier on the southeast Tibetan Plateau and its climatic sensitivity. J. Geophys. Res., 118, 1-16 (doi: 10.1002/jgrd.50760)

Yao TD and 14 others (2012) Different glacier status with atmospheric circulations in Tibetan Plateau and surroundings. Nat. Clim. Change, 2, 663-667 (doi: 10.1038/nclimate1580)

Zhao LJ and 7 others (2011) Isotopic evidence for the moisture origin and composition of surface runoff in the headwaters of the Heihe River basin. Chinese Sci. Bull., 56(4-5), 406-415 (doi: 10.1007/ s11434-010-4278-x) 